\title{
INSIGHTS INTO THE INFRARED AND RAMAN SPECTRA OF FRESH AND LYOPHILIZED ROYAL JELLY AND PROTEIN DEGRADATION IR SPECTROSCOPY STUDY DURING HEATING*
}

\author{
Sofija Lazarevska, Petre Makreski* \\ Institute of Chemistry, Faculty of Natural Sciences and Mathematics, \\ Ss. Cyril and Methodius University, Arhimedova 5, 1000 Skopje, Republic of Macedonia \\ "petremak@pmf.ukim.mk
}

\begin{abstract}
In terms of chemical composition, a honeybee secretion known as royal jelly (RJ) is very complex product containing water, proteins, carbohydrates, lipids, mineral salts and small amounts of polyphenols, vitamins and enzymes. Despite its chemical diversity, the bands originating from vibrational modes of the present proteins were successfully assigned in $1800-1200 \mathrm{~cm}^{-1}$ (Raman and IR) region where the interference of bands from other vibrational species is not substantial. The protein bands were attributed to amide I, amide II and amide III modes and their intensities, additionally, enabled to determine the protein secondary structures. The remaining bands up to $4000 \mathrm{~cm}^{-1}$ were attributed to other group vibrations whereas the region below $1200 \mathrm{~cm}^{-1}$ comprises bands from complex interacting modes within the major RJ components that can not be unequivocally attributed to distinct modes. The work also represents a pioneering effort to collect and interpret the Raman spectrum of fresh and lyophilized RJ samples and to correlate and describe the observed similarities/differences between IR and Raman spectra.
\end{abstract}

Keywords: royal jelly; infrared; Raman spectra; band assignments; protein degradation

\section{УВИД ВО ИНФРАЦРВЕНИТЕ И РАМАНСКИТЕ СПЕКТРИ НА СВЕЖ И ЛИОФИЛИЗИРАН МАТИЧЕН МЛЕЧ И СТУДИЈА ЗА ПРОТЕИНСКАТА ДЕГРАДАЦИЈА ПРИ ЗАГРЕВАЫЕ СЛЕДЕНА СО ИНФРАЦРВЕНА СПЕКТРОСКОПИЈА}

\begin{abstract}
Матичниот млеч (МM), кој претставува пчелин секрет, има комплексен хемиски состав и содржи: вода, протеини, јаглехидрати, масти, минерални соли и мало количество полифеноли, витамини и ензими. И покрај разновидноста во хемискиот состав, инфрацрвените и раманските ленти кои потекнуваат од присутните протеини беа успешно асигнирани во подрачјето од 1800 до $1200 \mathrm{~cm}^{-1}$. Тоа се должи на фактот што во оваа област интерференцијата, изразена преку преклопување на ленти од другите хемиски ентитети, е незначителна. Протеинските ленти беа припишани на модовите амид I, амид II и амид III, а интензитетите на лентите дополнително овозможија определување на секундарните структури на протеините. Другите спектрални ленти регистрирани до $4000 \mathrm{~cm}^{-1}$ беа асигнирани на други групови вибрации, додека во областа под 1200 $\mathrm{cm}^{-1}$ не може да се направи еднозначна интерпретација на спектрите поради силното преклопување помеѓу вибрационите ленти од многуте пристутни хемиски конституенти во ММ. Оваа студија претставува пионерски обид да се добијат и интерпретираат раманските спектри на свеж и лиофилизиран ММ како и да се корелираат и објаснат детектираните спектрални сличности/разлики помеѓу инфрацрвените и раманските спектри.
\end{abstract}

Клучни зборови: матичен млеч; инфрацрвен; рамански спектар; асигнација на ленти; протеинска деградација

\footnotetext{
- Dedicated to Academician Gligor Jovanovski on the occasion of his $70^{\text {th }}$ birthday.
} 


\section{INTRODUCTION}

Royal jelly (RJ) represents the sole food provided to female larvae, destined to become queens, by young workers or nurse bees of the common honey bee species Apis mellifica [1]. It keeps queen bees alive for 4 to 5 years whereas the worker bees, feeding on worker jelly, survive for a mere 3-4 weeks.

$\mathrm{RJ}$ is characterized by plethora of health beneficial properties showing antimetastatic action [2], antioxidative [3-7], hypoglycemic and immunological activities [8], cholesterol-lowering effects as well as estrogenic $[9,10]$ and anti-fatigue features [11].

This nourishing product is the secretion of a highly specialized set of hypopharyngeal and mandibular glands located in the head of worker bees aged between 5 and 15 days [12, 13]. It has been found that hypopharyngeal glands produced most of the components, whereas the mandibular glands enrich the RJ with fatty acids [14] of which, the most important active ingredient to fight bacteria, viruses and fungus is unsaturated fatty acid known as 10-hydroxy-2-decenoic acid (10-HDA) [15]. The RJ is homogeneous, creamy, milky-white colored fluid with slightly acid flavor ( $\mathrm{pH} 3.5-4.5)$ and strong and pungent odor [13].

A numerous investigations dedicated to evaluate the composition of RJ have been carried out aimed to identify the main building components. Chemically speaking, fresh RJ mainly comprises water (60-78\%), proteins (9-18\%), carbohydrates (7-18\%), lipids (3-8\%), 10-HDA (>1.4\%), mineral salts $(0.8-3 \%)$ and small amounts of polyphenols, vitamins and enzymes [16, 17]. On one hand, according to the complex composition comprising of major classes of biological macromolecules (proteins, lipids, carbohydrates), RJ is beneficial for human physiological functions but, on the other hand, the complex composition and dominant water content makes it very susceptible to adulteration and prone to crumbling. Adding the relatively high-price to the latter claim, it is of vital importance to provide an effective protocol for RJ temperature storage in order to retain its components unaltered. Beekeepers and apitherapists agree that fresh RJ placed under the tongue is the best way of consuming, whereas pharmaceutical companies suggest use in the form of powder. The method of converting the RJ to powder is called freeze-drying (lyophilization) and such product contains: water $(<5 \%)$, proteins $(27-41 \%)$, carbohydrates $(21-31 \%)$, lipids (8-19\%), 10-HDA $(>3.5 \%)[3,16]$.
Several studies are aimed to optimize the conditions for temperature storage and time duration before degradation of RJ components takes place. Chen and Chen [18], monitoring the content of carbohydrates, observed increase of glucose and fructose as a function of time, as well as simultaneous decrease of sucrose content due to inversion of the latter compound into specified simple sugars. The lipid class consists primarily of organic acids (80-90\%), most of which mono- and dihydroxy acids and dicarboxylic acids with 8 and 10 carbon atoms [13]. The recent work [11] has reported negligible 0.4 to $0.6 \%$ reduction in $10-\mathrm{HDA}$ acid in two RJ samples stored at room temperature for 12 months. It also revealed that compounds in this group are prone to conditions of storage and temperature and, although present in large amounts in RJ, are difficult to serve as indicator markers for RJ freshness. Third important major group comprises proteins and amino acids. The major present amino acids are proline, lysine, glutamic acid, $\beta$ alanine, phenylalanine, aspartate and serine [19]. No significant changes were observed in the overall concentration of free amino acids in RJ stored at $4{ }^{\circ} \mathrm{C}$ for 10 months [19]. However, proline and lysine content in the same samples stored at room temperature showed increase in the first three months and after 6-10 months decreased to levels slightly lower than those in the control samples. This suggests that, at favorable temperature conditions, a proteolytic enzymatic activity continues to occur over time [19]. However, the latest results published recently [20] signified that fresh RJ can be stored after harvest for much shorter period only seven weeks at $4{ }^{\circ} \mathrm{C}$ and up to 21 weeks at -20 ${ }^{\circ} \mathrm{C}$, whereas storage at room temperature for 3 days keeps protein stability in the product.

Having in mind that protein degradation in fresh and lyophilized RJ as a function of the (gradual) temperature increase is not reported, here, we conducted in situ ATR-IR spectroscopy work to elucidate this issue. In addition, the presentation and interpretation of bands in the Raman spectra of RJ has been carried out which, to the best of our knowledge, lacks for both fresh and lyophilized RJ.

\section{EXPERIMENTAL SECTION}

The fresh RJ was produced by Apis melifera macedonica honey bees and was used immediately after harvesting. Due to its thick and sticky consistency, this sample was termed as fresh-viscous $\mathrm{RJ}$, but when left at room temperature and ambient air for 5 minutes it solidified. The latter sample was denoted as fresh-solidified RJ. On the other 
hand, lyophilized RJ was supplied from China as first grade pure lyophilized RJ (10-HDA $\geq 6 \%$ ) in the form of light-yellow fine powder, processed directly from fresh royal jelly.

Attenuated total reflectance infrared (ATRIR) spectra on fresh and lyophilized RJ were collected on FT-IR PerkinElmer 2000 interferometer using a complete heatable Golden Gate ATR Mk II system $\left(\right.$ Specac $\left.^{\mathrm{TM}}\right)$ which consists of optics unit with ZnSe lenses, heatable diamond ATR topplate, baseplate, and an automatic temperature controller with RS232 control. Sapphire anvil was mounted to the micrometer clamp. The spectra were collected in the $4000-600 \mathrm{~cm}^{-1}$ region (resolution $4 \mathrm{~cm}^{-1}, 16$ scans per spectrum) from 20 to $100{ }^{\circ} \mathrm{C}$ with $5{ }^{\circ} \mathrm{C}$ step increments. The ATR-IR spectra in the $1750-1490 \mathrm{~cm}^{-1}$ were deconvoluted using the Gaussian/Lorentzian algorithm in Grams/32 Spectral Notebase ${ }^{\mathrm{TM}}$ (version 4.1) software (Galactic Industries Corporation). The ratio of peak area of 1545 and $1645 \mathrm{~cm}^{-1}$ bands [20] were used to follow the degradation of the protein structure as a function of the temperature.

The room temperature $\left(20^{\circ} \mathrm{C}\right)$ Raman spectra were recorded on micro-Raman multichannel spectrometer Horiba JobinYvon LabRam 300 Infinity. An Olympus MPlanN confocal microscope with $\times 50$ (long distance) objective for magnification was selected. In order to focus the laser beam, a confocal hole of about $2 \mu \mathrm{m}$ was used and the position on the sample surface was adjusted using motorized $x-y$ stage. The Raman effect was obtained using $632.8 \mathrm{~nm}$ line from a He:Ne laser with a power of $1.9 \mathrm{~mW}$. The backscattered radiation $\left(180^{\circ}\right.$ configuration) was analyzed with an 1800 lines/mm grating monochromator. Raman intensities were collected with a thermo-electrically cooled CCD array detector. The resolution of the system ("apparatus function") was $3 \mathrm{~cm}^{-1}$ and the wavenumber accuracy was $\pm 1 \mathrm{~cm}^{-1}$ (both calibrated with the Rayleigh line and the $520.5 \mathrm{~cm}^{-1}$ line of a Si standard). The acquisition time and the accumulation for each collected spectrum were set to $20 \mathrm{~s}$ and 20 scans, respectively.

\section{RESULTS AND DISCUSSION}

The bands in the ATR-IR spectra of freshviscous RJ, fresh-solidified RJ (RJ left at airconditions for several minutes) and lyophilized RJ (LRJ) occur in two well-separated regions: 3600 $2800 \mathrm{~cm}^{-1}$ and $1750-950 \mathrm{~cm}^{-1}$ (Fig. 1). The higherwavenumber region could not be used for sample discrimination because all spectra show great similarity. Here, the spectra consist of the strongest, wide and complex band with the maximum at 3280 $\mathrm{cm}^{-1}$ resulting as an overlap of the water stretching vibrations and $\mathrm{N}-\mathrm{H}$ stretchings from primary and secondary amines and the much weaker bands at 2930 and $2858 \mathrm{~cm}^{-1}$ from the $\mathrm{C}-\mathrm{H}$ stretching vibrations within the $-\mathrm{CH}_{2}-$ groups and secondary amines [20-22].

The second part of the spectrum from 1750 $1200 \mathrm{~cm}^{-1}$ is of particular interest for evaluation of the freshness of the RJ sample because of the presence of bands related to the vibrational modes arising from the protein molecular structure [20, 23]. Thus, infrared (and Raman) vibrational spectra can be used to estimate the secondary structure of proteins (which is defined by patterns of hydrogen bonds between backbone amide and carboxyl groups) by inspection of the frequencies at which the amide bonds absorb radiation [24-28].

The most significant features for identification of different protein backbone conformations are amide I (stretching vibration of $\mathrm{C}=\mathrm{O}$ ), amide II and amide III bands (Table 1). The latter two modes are associated with the coupled $\mathrm{C}-\mathrm{N}$ stretching and $\mathrm{N}-\mathrm{H}$ bending vibrations of the peptide bonds [29-32].

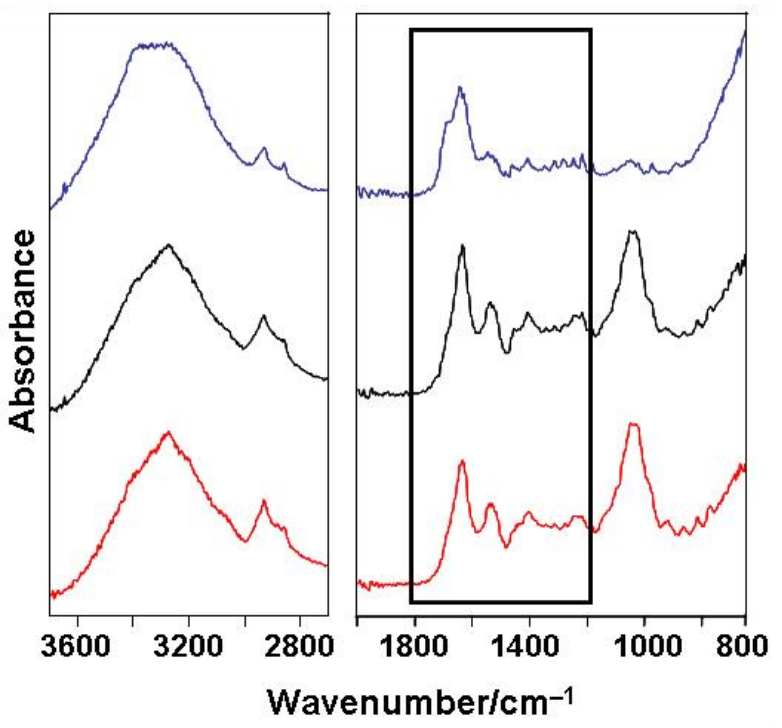

Fig. 1. ATR-IR spectra of fresh-viscous RJ (top), freshsolidified RJ (middle) and lyophilized RJ (bottom spectra). The protein bands are marked in the black rectangular.

The strongest bands occur in the 1700-1600 $\mathrm{cm}^{-1}$ region and are ascribed to amide I modes (Table 1) of the proteins present in the RJ [20]. Here, the spectrum of fresh-viscous RJ shows distinct differences from the fresh-solidified and lyophilized RJ spectra (Fig. 1). The spectral discrepancy is manifested by the appearance of weak band around $1690 \mathrm{~cm}^{-1}$ (which either becomes a shoul- 
der in the solidified RJ sample or disappears in the spectrum of LRJ sample). Furthermore, latter two samples exhibit sole band at $1640 \mathrm{~cm}^{-1}$ that, in the spectrum of the fresh-viscous RJ sample, is split into two components at 1646 and $1632 \mathrm{~cm}^{-1}$ (Fig. 1, Table 1). Although the IR spectra of RJ samples stored at different temperatures are reported [20, 23], such differences were neither registered nor discussed (Table 1). In the attempt to explain the spectral disparity in this region we would draw attention that such behavior is connected with the percentage variations among the $\alpha$-helical (spiral) conformation and $\beta$-sheets which describe the protein secondary structure [31]. Thus, the appearance of the band around $1690 \mathrm{~cm}^{-1}$ in the spectrum of fresh-viscous RJ implied larger percentage of $\beta$ sheets being lower in the fresh-solidified RJ and LRJ where the percentage of $\alpha$-helices is higher (Fig. 1 and Table 1). Namely, human serum albumine and bovine protein studies observed a progressive decrease of main contribution at $1650 \mathrm{~cm}^{-1}$ and the progressive increase of the two shoulders at 1620 and $1680 \mathrm{~cm}^{-1}$, typically attributed to intermolecular $\beta$-sheet structures [29-31]. The growth of these shoulders is correlated to the partial loss of the native $\alpha$-helix secondary structure suggesting a transition between these two secondary structures.

\section{Table 1}

Characteristic IR bands in RJ arising from the protein secondary structure. The assignment is carried out in accordance with the literature for corresponding IR bands in various protein sources.

\begin{tabular}{|c|c|c|c|c|c|c|}
\hline $\begin{array}{l}\text { Fresh- } \\
\text { viscous RJ }\end{array}$ & $\begin{array}{l}\text { Fresh-solidified } \\
\text { RJ and LRJ }\end{array}$ & Ref. [20] & Ref. [23] & Ref. [29] & Ref. [30] & Ref. [31] \\
\hline $1693 \mathrm{w}^{\mathrm{a}}$ & $1692 \mathrm{sh}^{\mathrm{b}}$ & 1692 & & & $\begin{array}{l}1690 \text { (amide I) } \\
\beta \text {-turn }\end{array}$ & $\begin{array}{l}1660-1700 \text { (amide I) } \\
\beta \text {-turn }\end{array}$ \\
\hline 1646 vs & $1640 \mathrm{vs}$ & 1640 & 1647 & 1655 (amide I) & $\begin{array}{l}1650 \text { (amide I) } \\
\alpha \text {-helix structure }\end{array}$ & $\begin{array}{l}1650-1658 \text { (amide I) } \\
\alpha \text {-helix structure }\end{array}$ \\
\hline $1632 \mathrm{w}$ & - & 1622 & - & 1610 (amide I) & $\begin{array}{l}1610 \text { (amide I) } \\
\beta \text {-helix structure }\end{array}$ & $\begin{array}{l}1610-1640 \text { (amide I) } \\
\beta \text {-sheet }\end{array}$ \\
\hline $1542 \mathrm{w}$ & $1542 \mathrm{~m}$ & 1545 & 1541 & 1540 (amide II) & 1540 (amide II) & 1548 (amide II) \\
\hline $1460 \mathrm{w}$ & $1460 \mathrm{w}$ & $\sim 1460$ & - & - & 1455 (amide II) & \\
\hline $1410 \mathrm{w}$ & $1410 \mathrm{w}$ & $\sim 1410$ & 1409 & - & 1410 (amide II) & \\
\hline $1318 \mathrm{w}$ & $1318 \mathrm{vw}$ & - & - & 1330 (amide III) & & \\
\hline $1286 \mathrm{w}$ & $1286 \mathrm{vw}$ & - & - & 1280 (amide III) & & \\
\hline $1251 \mathrm{w}$ & $1251 \mathrm{vw}$ & - & 1247 & 1254 (amide III) & & \\
\hline $1219 \mathrm{w}$ & $1219 \mathrm{w}$ & - & - & & & \\
\hline $1187 \mathrm{w}$ & $1187 \mathrm{w}$ & - & - & & & \\
\hline $1048 \mathrm{w}$ & 1048 vs & 1048 vs & 1054 & & & \\
\hline $978 \mathrm{w}$ & $978 \mathrm{sh}$ & & & & & \\
\hline
\end{tabular}

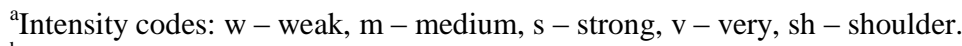

${ }^{\mathrm{b}}$ Absent in the spectrum of LRJ.

Going towards lower wavenumbers, the bands in the $1600-1400 \mathrm{~cm}^{-1}$ arise from the amide II bands [29]. In this region, the spectra depict much similar pattern confirming that these bands are less susceptible to treatment of RJ (Fig. 1). An exception is the $1540 \mathrm{~cm}^{-1}$ band which intensity increases with aging of the RJ sample being the weakest in the spectrum of fresh-viscous RJ sample. The decrease of amide I band at approximately $1650 \mathrm{~cm}^{-1}$ and the increase of amide II band at approximately $1450 \mathrm{~cm}^{-1}$ are strictly related, suggesting that an exchange occur in our sample, indicative of a conformational changes at a tertiary structural level. Therefore, the intensity ratio between the strongest amide I band at $1650 \mathrm{~cm}^{-1}$ and the $1540 \mathrm{~cm}^{-1}$ band from amide II vibrations is used to determine the protein degradation as a function of the temperature for both fresh and lyophilized RJ sample (see forthcoming discussion).

The bands in the $1400-1200 \mathrm{~cm}^{-1}$ region are ascribed to amide III modes and show the lowest degree of difference among the presented spectra (Fig. 1). The most significant disparity between the IR spectra of fresh-viscous RJ is the strong intensity of the band around $1050 \mathrm{~cm}^{-1}$ being considerably weaker in the spectra of solidified RJ and LRJ. The origin of the band is likely to be connected to $\mathrm{C}-\mathrm{O}$ stretchings arising from oxidation of the initial fresh sample left on air atmosphere. One probable suggestion is that ambient conditions trigger oxidation of the present carbohydrates in the RJ, i.e. oxidation of the free aldehyde carbonyl group (in simple sugars) to $\mathrm{C}-\mathrm{O}$ group (in alcohols) takes place. 
The reason for absence of the Raman spectrum of royal jelly in the literature is probably due to its weak scattering character making its collection a complex and elusive task. However, after careful adjustment of the instrumental conditions (given in the Experimenal section), representative Raman spectra were collected for fresh-viscous RJ, fresh-solidified RJ and LRJ (Fig. 2). Here, an attempt was made to conduct tentative band assignment (Table 2) in accordance with the IR discussion. The Raman band around $3285 \mathrm{~cm}^{-1}$ arising from the overlap of the water stretching vibrations and $\mathrm{N}-\mathrm{H}$ stretchings from primary and secondary amines is significantly lower in comparison with the IR analogues which is expected having in mind that water molecules are very weak scatterers. The remaining bands at 2930, 2895 and $2855 \mathrm{~cm}^{-1}$ appear from the $\mathrm{C}-\mathrm{H}$ stretching vibrations within the $-\mathrm{CH}_{2}-$ groups and secondary amines (the corresponding IR bands are reported in Ref. [20-22]), but the absence of the latter band in the solidified and LRJ spectra suggested that it probably appears from the aldehyde $\mathrm{C}-\mathrm{H}$ stretching vibration (Fig. 2 , right panel). Namely, when fresh-viscous RJ is left on ambient conditions, oxidation of the free aldehyde carbonyl group (from the simple sugars) occurred diminishing the corresponding $\mathrm{C}-\mathrm{H}$ stretching band.

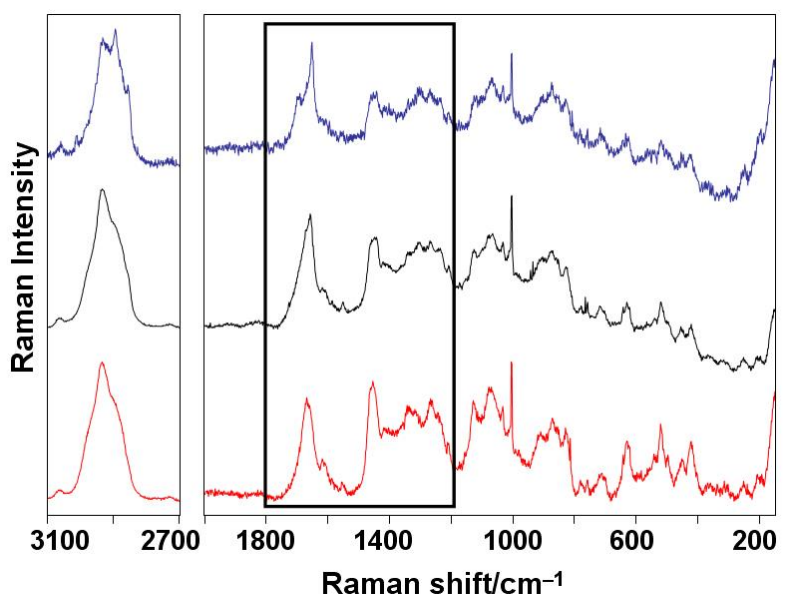

Fig. 2. Raman spectra of fresh-viscous RJ (top), freshsolidified RJ (middle) and lyophilized RJ (bottom spectra).

The protein bands are marked in the black rectangular.

The only difference between the Raman spectrum of fresh-viscous RJ and the remaining two spectra (Fig. 2, Table 2) is reflected in the appearance of weak amide I band at $1695 \mathrm{~cm}^{-1}$. Its presence implies larger percentage of $\beta$-sheets (in the secondary structure of the proteins) being low- er in the fresh-solidified RJ and LRJ where the percentage of $\alpha$-helices is higher. The strongest band at $1650-1660 \mathrm{~cm}^{-1}$ and much weaker absorption around $1610 \mathrm{~cm}^{-1}$ originate from amide I modes representing dominant presence of $\alpha$-helices over the $\beta$-helix secondary structure of proteins (Table 2 and Fig. 2). The assignment of the bands at 1552,1454 and $1414 \mathrm{~cm}^{-1}$, as well as the bands at 1340,1303 and $1269 \mathrm{~cm}^{-1}$, is made according to the IR considerations and the bands are ascribed to amide II and amide III modes, respectively (Table 2). It is obvious that the treatment of RJ sample does not involve changes in the Raman spectra, and therefore these bands can not be considered for discriminative purposes in the protein degradation studies.

The region below $1200 \mathrm{~cm}^{-1}$ presents band absorptions that can not be unequivocally attributed to any distinct vibrations because they correspond to complex interacting vibrational modes within the major components present in the RJ.

\section{Table 2}

Characteristic Raman bands in RJ arising from the secondary structure of proteins and their tentative assignment

\begin{tabular}{|c|c|c|}
\hline $\begin{array}{l}\text { Fresh- } \\
\text { viscous RJ }\end{array}$ & $\begin{array}{l}\text { Fresh-solidified } \\
\text { RJ and LRJ }\end{array}$ & "Assignment \\
\hline $1695 \mathrm{w}^{\mathrm{a}}$ & & Amide I, $\beta$-turn \\
\hline $1651 \mathrm{~s}$ & $1660 \mathrm{~s}$ & $\begin{array}{l}\text { Amide I, } \alpha \text {-helix } \\
\text { structure }\end{array}$ \\
\hline $1610 \mathrm{vw}$ & $1611 \mathrm{vw}$ & $\begin{array}{l}\text { Amide I, } \beta \text {-helix } \\
\text { structure }\end{array}$ \\
\hline $1552 \mathrm{vw}$ & $1552 \mathrm{w}$ & Amide II \\
\hline $1454 \mathrm{~m}$ & $1454 \mathrm{~s}$ & Amide II \\
\hline $1414 \mathrm{vw}$ & $1416 \mathrm{vw}$ & Amide II \\
\hline $1340 \mathrm{vw}$ & $1342 \mathrm{vw}$ & Amide III \\
\hline $1303 \mathrm{w}$ & $1303 \mathrm{vw}$ & Amide III \\
\hline $1269 \mathrm{w}$ & $1268 \mathrm{vw}$ & Amide III \\
\hline $1236 \mathrm{w}$ & $1236 \mathrm{w}$ & \\
\hline $1209 \mathrm{vw}$ & $1209 \mathrm{vw}$ & \\
\hline $1126 \mathrm{vw}$ & $1125 \mathrm{w}$ & \\
\hline $1068 \mathrm{w}$ & $1067 \mathrm{vw}$ & \\
\hline $1033 \mathrm{vw}$ & $1033 \mathrm{vw}$ & \\
\hline $1004 \mathrm{vw}, \mathrm{sh}$ & $1002 \mathrm{vw}$ & \\
\hline
\end{tabular}

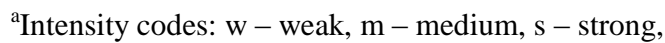
$\mathrm{v}$ - very, sh - shoulder.

As reported above, the intensity ratio (R) between the amide II band at $1540 \mathrm{~cm}^{-1}$ and the 1640 $\mathrm{cm}^{-1}$ band from amide I vibrations $[\mathrm{R}=\operatorname{Area}(1545$ $\left.\mathrm{cm}^{-1}\right) /$ Area $\left.\left(1640 \mathrm{~cm}^{-1}\right)\right]$, from the ATR-IR spectral region (Fig. 3) is used to determine the protein degradation as a function of the temperature for both fresh and lyophilized RJ samples. Similar study on protein degradation during storage of fresh 
RJ sample at temperatures of $-20,+4$ and $+25{ }^{\circ} \mathrm{C}$ showed maintenance of the protein stability up to 21 weeks, seven, and three days, respectively [20].

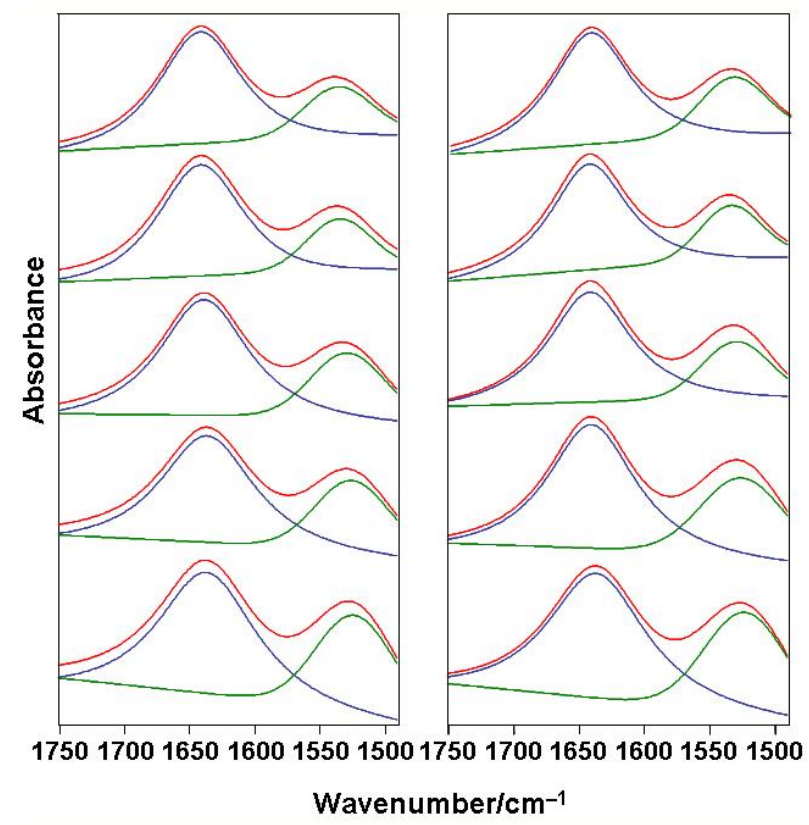

Fig. 3. Fitted ATR-IR spectra (1750-1490 $\mathrm{cm}^{-1}$ region) of fresh RJ (left panel) and lyophilized RJ (right panel) on selected temperatures: $+20,+40,+60,+80$, and $+100{ }^{\circ} \mathrm{C}$ (top-down presentation)

Table 3 presents the calculated ratio of the above areas for fresh and lyophilized RJ plotted as a function of the temperature. As seen, the ratio for fresh RJ increases from $0.266 \pm 0.003\left(20{ }^{\circ} \mathrm{C}\right)$ to $0.359 \pm 0.002$ (at $100{ }^{\circ} \mathrm{C}$ ) whereas similar trend was obtained for LRJ sample starting from $0.288 \pm$ $0.002\left(20^{\circ} \mathrm{C}\right)$ to $0.403 \pm 0.001$ (at $100{ }^{\circ} \mathrm{C}$ ). The overall increase of the band area of the ascertained amide II band is $34.96 \%$ in the fresh RJ series whereas the lyophilized RJ series showed somewhat higher percentage rise $(39.59 \%)$.

Additional similarity among the two series is reflected in the increase of the ratio obtained above $30{ }^{\circ} \mathrm{C}$, showing slow, but notable rise that lasts until $65-70{ }^{\circ} \mathrm{C}$ after which the ratio increased more dramatically. Fig. 4 depicts graphical dependence of ratio against temperature $(T)$ fitted, using polynomial function of degree 4 (drawn using OriginPro $\left.{ }^{\circledR} 8, \mathrm{v} 8.0951\right)$. The corresponding equation is $R=-2 \cdot 10^{-8} T^{4}+4 \cdot 10^{-6} T^{3}-0.0003 T^{2}+$ $0.0104 T+0.1497\left(R^{2}=0.9739\right)$ for fresh $\mathrm{RJ}$ and $\mathrm{R}$ $=-3 \cdot 10^{-8} T^{4}+6 \cdot 10^{-6} T^{3}-0.0005 T^{2}+0.0149 T+$ $0.124\left(R^{2}=0.9743\right)$ for lyophilized RJ sample. Thus, one can conclude that, from protein nondisintegration point of view, safe temperatures are those below $30^{\circ} \mathrm{C}$.
Table 3

Ratio $(R)$ of the $1545 \mathrm{~cm}^{-1}$ band area and $1640 \mathrm{~cm}^{-1}$ band area (indicative for protein degradation) obtained from in situ temperature-dependent ATR-IR spectra of fresh and lyophilized RJ

\begin{tabular}{lll|lll}
\hline $\begin{array}{l}\text { Temp. } \\
{ }^{\circ} \mathrm{C}\end{array}$ & $\begin{array}{l}\text { R for } \\
\text { fresh-RJ }\end{array}$ & $\begin{array}{l}\text { R for } \\
\text { LRJ }\end{array}$ & $\begin{array}{l}\text { Temp. } \\
{ }^{\circ} \mathrm{C}\end{array}$ & $\begin{array}{l}\text { R for } \\
\text { fresh-RJ }\end{array}$ & $\begin{array}{l}\text { R for } \\
\text { LRJ }\end{array}$ \\
\hline 20 & 0.266 & 0.288 & 65 & 0.295 & 0.328 \\
25 & 0.265 & 0.289 & 70 & 0.296 & 0.367 \\
30 & 0.264 & 0.290 & 75 & 0.318 & 0.379 \\
35 & 0.277 & 0.309 & 80 & 0.323 & 0.395 \\
40 & 0.280 & 0.309 & 85 & 0.349 & 0.403 \\
45 & 0.279 & 0.319 & 90 & 0.359 & 0.405 \\
50 & 0.277 & 0.321 & 95 & 0.358 & 0.403 \\
55 & 0.290 & 0.319 & 100 & 0.359 & 0.402 \\
60 & 0.293 & 0.326 & & & \\
\hline \hline
\end{tabular}

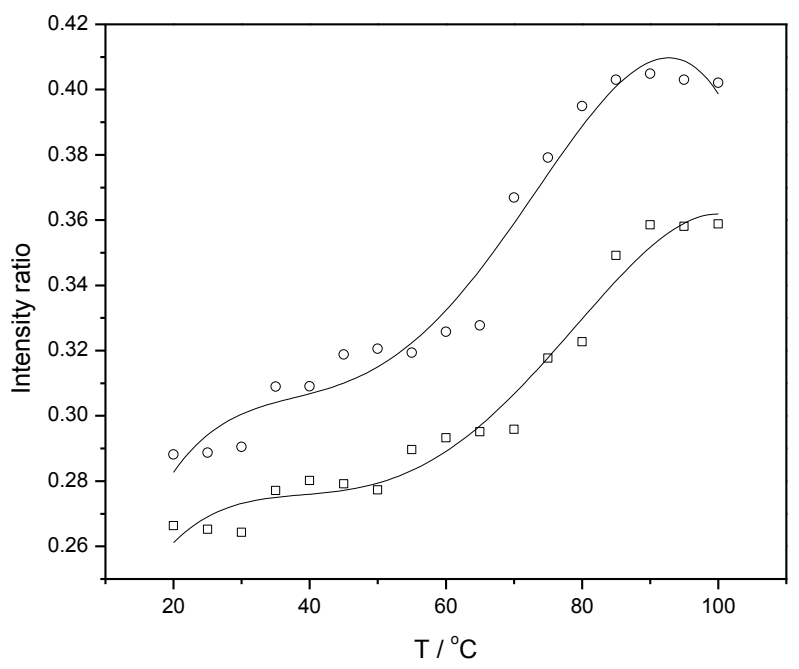

Fig. 4. Change of the ratio $\left(1540 \mathrm{~cm}^{-1} / 1640 \mathrm{~cm}^{-1}\right.$ band area) and added trend line as a function of the temperature (squares - fresh RJ series, circles - lyophilized RJ series)

\section{CONCLUSIONS}

The conducted temperature-induced ATR-IR study revealed that temperature increase speed up protein degradation, manifested by the increase of the ratio between the intensity of amide II (1542 $\left.\mathrm{cm}^{-1}\right)$ and amide I $\left(1640 \mathrm{~cm}^{-1}\right)$ band. ATR-IR spectra collected by gradient temperature increase from RT to $100{ }^{\circ} \mathrm{C}$ (step $5{ }^{\circ} \mathrm{C}$ ) have shown that protein degradation in both fresh and lyophilized RJ samples starts around $30^{\circ} \mathrm{C}$ being significantly accelerated around $65-70^{\circ} \mathrm{C}$. Additionally, we succeeded in collecting the Raman spectra of pure fresh and lyophilized RJ samples (not found in the literature) and, as in the case of ATR-IR spectra, tentatively assigned the bands from 4000 to $1200 \mathrm{~cm}^{-1}$. Therefore, Raman and ATR-IR spectroscopy are 
considered as complementary and powerful techniques for screening of the molecular structure of the proteins present in RJ.

Acknowledgements. The financial support from the Ministry of Education and Science of Republic of Macedonia is appreciated (PM).

\section{REFERENCES}

[1] S. A. Barker, A. B. Foster, D. C. Lamb, L. M. Jackman, Components of royal jelly, 10-hydroxy-trans-dec-2enoic acid, Tetrahedron, 18, 177-181 (1962).

[2] T. Tamura, A. Fujii, N. Kuboyama, Antitumor effects of royal jelly (RJ), Nippon Yakurigaku Zasshi, 89, 73-80 (2000).

[3] A. Karaali, F. Meydanoglu, D. Eke, Studies on composition, freeze-drying and storage of Turkish royal jelly, $J$. Apicult. Res., 27, 182-185 (1988).

[4] J. Iannuzzi, Royal jelly: mystery food, Am. Bee J., 130, 587-589 (1990).

[5] T. Nagai, R. Inoue, Preparation and the functional properties of water extract and alkaline extract of royal jelly, Food Chem., 84, 181-186 (2004).

[6] T. Nagai, M. Sakai, R. Inoue, H. Inoue, N. Suzuki, Antioxidative activities of some commercially honeys, royal jelly, and propolis, Food Chem., 75, 237-240 (2001).

[7] S. Inoue, S. Koya-Miyata, S. Ushio, K. Iwaki, M. Ikeda, M. Kurimoto, Royal jelly prolongs the life span of $\mathrm{C} 3 \mathrm{H} / \mathrm{HeJ}$ mice: correlation with reduced DNA damage, Exp. Gerontol., 38, 965-969 (2003).

[8] M. Genç, A. Aslan, Determination of trans-10-hydroxy2-decenoic acid content in pure royal jelly and royal jelly products by column liquid chromatography, J. Chromatogr. A, 839, 265-268 (1999).

[9] S. Mishima, K. M. Suzuki, Y. Isohama, N. Kuratsu, Y. Araki, M. Inoue, T. Miyata, Royal jelly has estrogenic effects in vitro and in vivo, J. Ethnopharm., 101, 215220 (2005)

[10] K. Shinnosuke, L. B. de Almeida-Muradian, Application of HPLC to measure 10-hydroxy-2-decenoic acid in pure royal jelly and Brazilian honey with royal jelly, Quim. Nova, 26, 670-673 (2003).

[11] J. F. Antinelli, S. Zeggane, R. Davico, C. Rognone, J. P. Faucon, L. Lizzani, Evaluation of (E)-10-hydroxydec-2enoic acid as a freshness parameter for royal jelly, Food Chem., 80, 85-89 (2003).

[12] R. B. Willson, Royal jelly: a review, Am. Bee J., 95, 1521 (1955).

[13] G. Lercker, M. F. Caboni, M. A. Vecchi, A. G. Sabatini, Caratterizzazione dei principali costituenti della gelatina reale, Apicoltura, 8, 27-37 (1993).

[14] E. Plettner, K. N. Slessor, M. L. Winston, Biosynthesis of mandibular acids in honey bees (Apis mellifera): de novo synthesis, route of fatty acid hydroxylation and caste selective B-oxidation, Insect Biochem. Mol. Biol., 28, 31-42 (1998).

[15] A. Butenandt, H. Rembold, Über den Weiselzellenfuttersaft der Honigbiene, I. Isolierung, Konstitutionsermittlung und
Vorkommen der 10-Hydroxy- $\Delta 2$-decensäure, HoppeSeyler's Z. physiol. Chem., 308, 284-289 (1957).

[16] A. G. Sabatini, G. L. Marcazzan, M. Fiorenza Caboni, S. Bogdanov, L. B. de Almeida-Muradian, Quality and standardisation of royal jelly, J. ApiProd. ApiMed. Sci., 1, 1-6 (2009).

[17] V. A. Isidorov, S. Bakier, I. Grzech, Gas chromatographic-mass spectrometric investigation of volatile andextractable compounds of crude royal jelly, J. Chromatogr. B, 885-886, 109-116 (2012).

[18] C. Chen, S.-Y. Chen, Changes in protein components and storage stability of royal jelly under various conditions, Food Chem., 54, 195-200 (1995).

[19] E. Boselli, M. F. Caboni, A. G. Sabatini, G. L. Marcazzan, G. Lercker, Determination and changes of free amino acids in royal jelly during storage, Apidologie, 34, 129-137 (2003).

[20] P. A. Tarantilis, C. S. Pappas, E. Alissandrakis, P. C. Harizanis, G. G. Polissiou, Monitoring of royal jelly protein degradation during storage using Fourier-transform infrared (FTIR) spectroscopy, J. Apicult. Res., 51, 185192 (2012)

[21] G. Socrates, Infrared characteristic group frequencies, 2nd edition, John Wiley \& Sons, New York, USA, 1997.

[22] R. Venu, T. S. Ramulu, S. Anandakumar, V. S. Rani, C. G. Kim, Bio-directed synthesis of platinum nanoparticles using aqueous honey solutions and their catalytic applications, Colloid Surface A, 384, 733-738 (2011)

[23] L. M. Wu, Q. Zhou, J. Zhao S. Q. Sun, F. L. Hu, Research on overall assessment of royal jelly freshness by FTIR spectroscopy, Spectrosc. Spect. Anal., 29, 32363240 (2009).

[24] S. Krimm, J. Bandekar, Vibrational spectroscopy and conformation of peptides, polypeptides, and proteins, Adv. Protein. Chem., 38, 181-364 (1986).

[25] R. W. William, Protein secondary structure analysis using Raman Amide I and Amide III spectra, Method Enzymol., 130, 311-331 (1986)

[26] J. Banker, Amide modes and protein conformation, Biochim. Biophys. Acta, 1120, 123-143 (1992).

[27] J. Kong, S. Yu, Fourier Transform Infrared Spectroscopic Analysis of Protein Secondary Structures, Acta Biochim. Biophys. Sin., 39, 549-559 (2007).

[28] Z-Q. Wen, Raman spectroscopy of protein pharmaceuticals, J. Pharm. Sci., 96, 2861-2878 (2007).

[29] E. J. Castillo, J. L. Koenig, J. M. Anderson, Characterization of protein adsorption on soft contact lenses, Biomaterials, 5, 319-325 (1984).

[30] V. Militello, C. Casarino, A. Emanuele, A. Giostra, F. Pullana, M. Leone, Aggregation kinetics of bovine serum albumin studied by FTIR spectroscopy and light scattering, Biophys. Chem., 107, 175-187 (2004).

[31] J. Tang, F. Luan, X. Chen, Binding analysis of glycyrrhetinic acid to human serum albumin: Fluorescence spectroscopy, FTIR, and molecular modelling, Bioorgan. Med. Chem., 14, 3210-3217 (2006)

[32] D. Krilov, M. Balarin, M. Kosovic, O. Gamulin, J. BrnjasKraljevic, FT-IR spectroscopy of lipoproteins - a comparative study, Spectrochim. Acta A, 73, 701-706 (2009). 
